\title{
ANALISIS PENGURANGAN WASTE PADA PROSES PERAWATAN KERETA
}

\author{
Analysis of Waste Reduction in Train Care Process
}

\author{
Ardiansyah Odi ${ }^{1}$, Akhmad Nidhomuz Zaman ${ }^{1}$, Siti Rohana Nasution ${ }^{2 *}$, Sambas \\ Sundana ${ }^{2}$
}

${ }^{1}$ Teknik Industri, FT UPN "Veteran" Jakarta,Jl. RS Fatmawati Pondok Labu Jakarta Selatan 12450, Indonesia

${ }^{2}$ Teknik Industri, FT Univ. Pancasila, Jl. Srengseng Sawah Jagakarsa, Jakarta Selatan 12640, Indonesia

Informasi artikel

Diterima: $23 / 02 / 2019$ Direvisi : 25/02/2019 Disetujui: 25/02/2019

\begin{abstract}
Abstrak
Tulisan ini menjelaskan tentang identifikasi waste pada perawatan kereta bagian bogie dan memberikan rekomendasi perbaikan yang bertujuan untuk mengurangi waste yang terjadi. Dengan menggunakan pendekatan lean concept yang lebih dominan ke arah lean service, penelitian ini dimulai dengan menggambarkan big picture mapping dan pembobotan nilai waste berdasarkan kuesioner menggunakan VALSAT. Waste juga diidentifikasi menggunakan fault tree analysis yang selanjutnya dilakukan perhitungan nilai kritis waste menggunakan FMEA kemudian dilakukan rekomendasi perbaikan menggunakan pendekatan $5 \mathrm{~W}+1 \mathrm{H}$. Hasil perhitungan berdasarkan data yang dikumpulkan, didapatkan bahwa total lead time pengerjaan perawatan kereta yang sebelumnya sebesar 995 menit menjadi 873 menit. Dengan presentase dari value added activity sebesar $93 \%$ dan non - necessary value adding sebesar $7 \%$. Dan berdasarkan analisa FMEA didapatkan bahwa waste kritis yang diperlukan perbaikan adalah waste unnecessary motion dengan skor RPN sebesar 140.
\end{abstract}

Kata Kunci: waste, lean service, VALSAT,FMEA, fault tree analysis.

\begin{abstract}
This paper describes the identification of waste in the maintenance of bogie parts and provides recommendations for improvements aimed at reducing waste that occurs. By using a lean concept approach that is more dominant towards lean service, this research begins by describing the big picture mapping and weighting of waste values based on a questionnaire using VALSAT. Waste is also identified using a fault tree analysis, which then calculates the critical value of waste using FMEA and then makes recommendations for improvements using the $5 \mathrm{~W}+1 \mathrm{H}$ approach. Calculation results based on the data collected, it was found that the total lead time of the previous train maintenance work of 995 minutes became 873 minutes with a percentage of value-added activity of $93 \%$ and nonnecessary value adding of $7 \%$. And based on the FMEA analysis, it was found that the critical waste needed for improvement was waste unnecessary motion with an RPN score of 140.
\end{abstract}

Keywords: waste, lean service, VALSAT, FMEA, fault tree analysis.

\footnotetext{
* Penulis Korespondensi: +62 8161400836
} 


\section{PENDAHULUAN}

Setiap perusahaan yang didirikan pasti memiliki tujuan dan visi - misi perusahaan itu sendiri, untuk mencapai tujuan tersebut tidaklah mudah, karena dipengaruhi berbagai faktor. Salah satu faktor paling penting yang mempengaruhi pencapaian tujuan pada industri pelayanan jasa, adalah terjadinya pemborosan (waste) yang menyebabkan waktu pengerjaan selama proses pelayanan menjadi lebih lama dari ketentuan yang telah ditetapkan. Dalam industri jasa pengertian waste dapat dipahami sebagai suatu aktivitas yang tidak sesuai dengan proses pelayanan konsumen yang memberikan dampak pada proses lainnya.

PT. XYZ adalah sebuah industri jasa dimana objek pengerjaannya adalah perawatan kereta. Bila mengacu pada peraturan yang ditetapkan pada perusahaan, lead time yang dibutuhkan satu rangkaian kereta untuk dilakukan perawatan paling lama adalah satu bulan atau 30 hari. Namun pada pelaksanaannya selalu terjadi deviasi dari lead time tersebut, atau dengan kata lain terjadi pemborosan (waste) selama proses perawatan kereta sehingga mengakibatkan waktu pengerjaan melewati dari jadwal yang telah ditetapkan. Hal tersebut dapat dibuktikan pada tabel realisasi perawatan kereta tiap bulan yang terjadi pada tahun 2017 sebagai berikut:

Tabel 1 Realisasi Perawatan Kereta 2017

\begin{tabular}{|c|c|c|c|c|c|c|c|}
\hline \multirow{2}{*}{ Bulan } & \multirow{2}{*}{\begin{tabular}{|c|}
$\begin{array}{c}\text { Jenis Rangkaian } \\
\text { Kereta }\end{array}$ \\
\end{tabular}} & \multicolumn{3}{|c|}{ Tanggal } & \multicolumn{3}{|c|}{ Durasi } \\
\hline & & Masuk & TECO & Keluar & Pesanan & Peng & jian \\
\hline Jamuari & A8 & 09-01-201 & $31-01-201$ & $17-02-2017$ & 24 & 58 & hari \\
\hline Februari & A6 & 14-02-201 & $28-02-201$ & $31-03-2017$ & 26 & 35 & hari \\
\hline Maret & A5 & 20-03-201 & $31-03-201$ & 26-04-2017 & 30 & 29 & hari \\
\hline April & A85 & $10-04-201$ & $29-04-201$ & $19-05-2017$ & 28 & 47 & hari \\
\hline Mei & A5 & $18-05-201$ & $31-05-201$ & 19.06 .2017 & 20 & 32 & hari \\
\hline Juni & A85 & 19-06-201' & $30-06.201$ & $18-07.2017$ & 29 & 42 & hari \\
\hline Juli & A5 & 17-07-201 & $31-07.201$ & 11.08 .2017 & 28 & 33 & hari \\
\hline Agustus & A7 & $14-08-201$ & $31-08.201$ & 18.09.2017 & 29 & 35 & hari \\
\hline September & $\mathrm{Al}$ & $18-09-201$ & $29-09-201$ & 21.10 .2017 & 29 & 51 & hari \\
\hline Oktober & A6 & 23-10-201 & 31-10-201 & 24-11-2017 & 30 & 38 & hari \\
\hline Nopember & A6 & $21-11-201$ & $30-11-201$ & $17-12-2017$ & 23 & 36 & hari \\
\hline Desember & A85 & $\mid 15-12-201$ & $29-12-201$ & $12-01-2018$ & 25 & 49 & hari \\
\hline
\end{tabular}

Berdasarkan permasalahan diatas, dilakukan identifikasi dan minimisasi dari waste yang terjadi pada proses perawatan kereta dengan menggunakan pendekatan Lean Service. Identifikasi dilakukan pada ruas perawatan bogie.

\section{Lean Service}

Lean service adalah sekumpulan peralatan dan metode yang dirancang untuk mengeliminasi waste, mengurangi waktu tunggu, memperbaiki performansi, dan mengurangi biaya. Menurut sumber lain, lean adalah mengeliminasi waste dan menciptakan customer value, dan terdiri dari beberapa prinsip yang menjadi landasan filosofinya. (Setyaningsih, 2013)

Lean service dalam bidang pelayanan menyandang prinsip yang sama dengan lean manufacture, yaitu melakukan perbaikan yang berkesinambungan dan menghilangkan aktivitas non-value adding dan waste.

\section{Big Picture Mapping}

Big picture mapping adalah pemetaan proses pada level tinggi yang melingkupi proses secara luas namun dengan tingkat kedetailan yang masih rendah. Peta gambar besar atau Big Picture Mapping merupakan sebuah alat yang diadopsi dari sistem produksi Toyota. Alat ini sangat membantu dalam mengidentifikasi terjadinya pemborosan (waste). Pemborosan dapat diketahui dengan mengetahui aliran fisik dan aliran informasi dari perusahaan dan menggambarkannya dalam satu kesatuan.

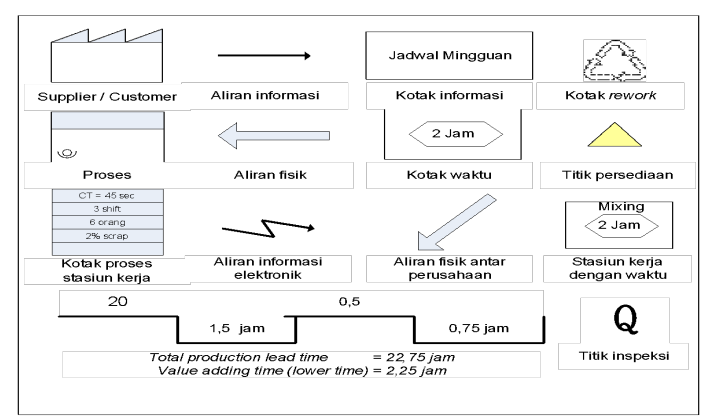

\section{Gambar 1 Simbol - simbol big picture mapping}

\section{Kuesioner}

Kuesioner merupakan daftar pertanyaan yang akan digunakan oleh peneliti untuk memperoleh data dari sumbernya secara langsung melalui proses komunikasi atau dengan mengajukan pertanyaan (Hendri, 2009). Kuesioner ini digunakan untuk mendapatkan ranking dan skor rata-rata waste yang, berikut adalah contoh dari tabel kuesioner: 
Tabel 2 Skor Kuesioner

\begin{tabular}{cll}
\hline No & \multicolumn{1}{c}{ Pemborosan } & $\begin{array}{c}\text { Skor } \\
(\mathbf{0 - 5 )}\end{array}$ \\
\hline 1 & Defects (kecacatan) & \\
2 & Overproduction (produksi berlebih) & \\
3 & Waiting (menunggu) \\
4 & Transportation (transportasi berlebih) \\
5 & Unnecessary inventory (persediaan & \\
6 & yang tidak perlu) \\
7 & Ootion (gerakan yang tidak perlu) & \\
\hline
\end{tabular}

Value Stream Analysis Tools (VALSAT)

Value Stream Analysis Tools (VALSAT) adalah alat yang berfungsi untuk memilih alat dari pemetaan aliran proses yang nantinya akan digunakan sebagai pedoman dalam mengidentifikasi pemborosan (waste). Value stream analysis tools merupakan tools yang tepat untuk memetakan secara detail waste pada aliran nilai yang fokus pada value adding process dan non-value adding process. Berikut ini adalah tools yang digunakan pada value stream analysis tools yang ditunjukkan sebagai berikut:

\section{Tabel 3 Value Stream Analysis Tools}

\begin{tabular}{|c|c|c|c|c|c|c|c|}
\hline Waste & $\begin{array}{l}\text { Process } \\
\text { Activity } \\
\text { Mapping }\end{array}$ & $\begin{array}{c}\text { Supply } \\
\text { Chain } \\
\text { Response } \\
\text { Matrix }\end{array}$ & $\begin{array}{c}\text { Production } \\
\text { Variety } \\
\text { Funnel }\end{array}$ & $\begin{array}{c}\text { Quality } \\
\text { Filter } \\
\text { Mapping }\end{array}$ & $\begin{array}{c}\text { Demand } \\
\text { Amplification } \\
\text { Mapping }\end{array}$ & $\begin{array}{l}\text { Decision } \\
\text { Paint } \\
\text { Analysis }\end{array}$ & $\begin{array}{l}\text { Physical } \\
\text { Structure }\end{array}$ \\
\hline Defects & $\mathrm{L}$ & - & - & - & - & - & - \\
\hline Over Production & $\mathrm{L}$ & M & - & $\mathrm{L}$ & M & M & - \\
\hline Waiting & $\mathrm{H}$ & $\mathrm{H}$ & $\mathrm{L}$ & - & M & $\mathrm{M}$ & - \\
\hline Transportation & $\mathrm{H}$ & - & 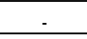 & - & - & - & $\mathrm{L}$ \\
\hline Un-Inventories & $\mathrm{M}$ & $\mathrm{H}$ & M & . & $\mathrm{H}$ & M & $\mathrm{L}$ \\
\hline Un-Motions & $\mathrm{H}$ & $\mathrm{L}$ & - & $\mathrm{H}$ & - & - & - \\
\hline In-Process & $\mathrm{H}$ & - & M & $\mathrm{L}$ & - & $\mathrm{L}$ & - \\
\hline
\end{tabular}

Catatan :

$\mathrm{H}$ : high correlation and usefulness, faktor pengali = $9 ; M$ :medium correlation and usefulness, faktor pengali $=6 ; \mathrm{L}:$ low correlation and usefulness, faktor pengali $=1$

\section{Fault Tree Analysis (FTA)}

Fault Tree Analysis merupakan sebuah analytical tool yang menerjemahkan secara grafik kombinasi - kombinasi dari kesalahan yang menyebabkan kegagalan dari sistem. Teknik ini berguna mendeskripsikan dan menilai kejadian didalam system (Ferdiana et al, 2015)

Pohon kesalahan adalah suatu model grafis yang menyangkut berbagai paralel dan kombinasi percontohan kesalahan kesalahan yang akan mengakibatkan kejadian dari peristiwa tidak diinginkan yang sudah didefinisi sebelumnya, atau juga dapat diartikan merupakan gambaran hubungan timbal balik yang logis dari peristiwa peristiwa dasar yang mendorong. Dibawah ini merupakan contoh dari penggunaan metode Fault Tree Analysis (FTA) adalah sebagai berikut:

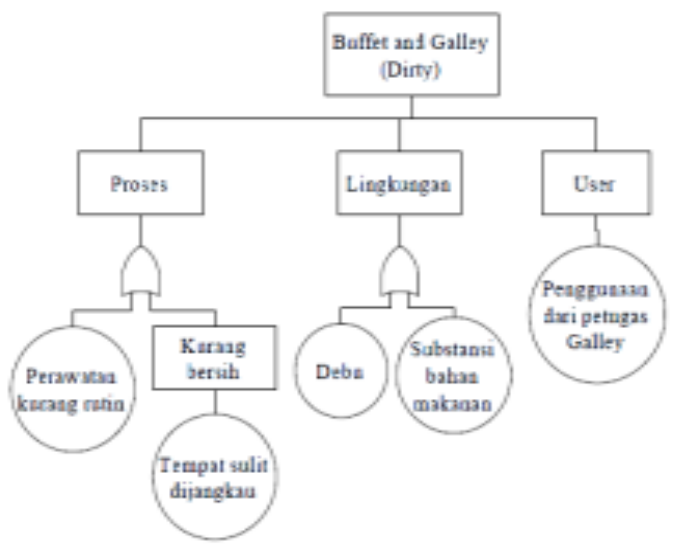

Gambar 2 Contoh Fault Tree Analysis

\section{Failure Mode Effect Analysis (FMEA)}

Failure Mode Effect Analysis (FMEA) merupakan suatu prosedur terstruktur untuk mengidentifikasi dan mencegah sebanyak mungkin mode kegagalan yang terjadi. Kegagalan adalah apa saja yang termasuk dalam kecacatan / kegagalan dakam desain, kondisi di luar batas spesifikasi yang ditetapkan, atau perubahan - perubahan dalam produk yang menyebabkan terganggunya fungsi dari produk itu. (Marastya, 2018)

Metode ini dikembangkan sekitar tahun 1960-an, ketika gerakan mutu mulai timbul. Pemakaian secaran formal dimulai di industri dirgantara pada saat itu, dimana kepedulian terhadap keselamatan penerbangan sangat tinggi. Sasaran awal FMEA adalah mencegah terjadinya kecelakaan.

Menggunakan FMEA tidak dapat dipisahkan dari penggunaan Risk Priority Number (RPN) yang merupakan hasil perkalian dari pembobotan suatu mode kegagalan. Adapun rumus dari RPN adalah (Adrianto \& Kholij, 2015):

RPN $=($ Nilai Dampak) $x$ (Nilai Kemungkinan) $x$ (Nilai Deteksi)

\section{METODOLOGI}

\section{Tahap - Tahap Penelitian}

Pada penelitian ini, tempat pengambilan data di lakukan di PT. XYZ yang bergerak di sebuah perusahaan jasa yang bertugas merawat kereta yang bertempat di Jawa Barat. Penelitian dilaksanakan pada tanggal 08 Januari 2018 sampai 08 Februari 2018 pada ruas pengerjaan perawatan frame dan suspensi. 
Berdasarkan pada latar belakang penelitian dan tinjauan pustaka yang ada, selanjutnya dilakukan metode penelitian dengan tahapan-tahapan sebagai berikut:

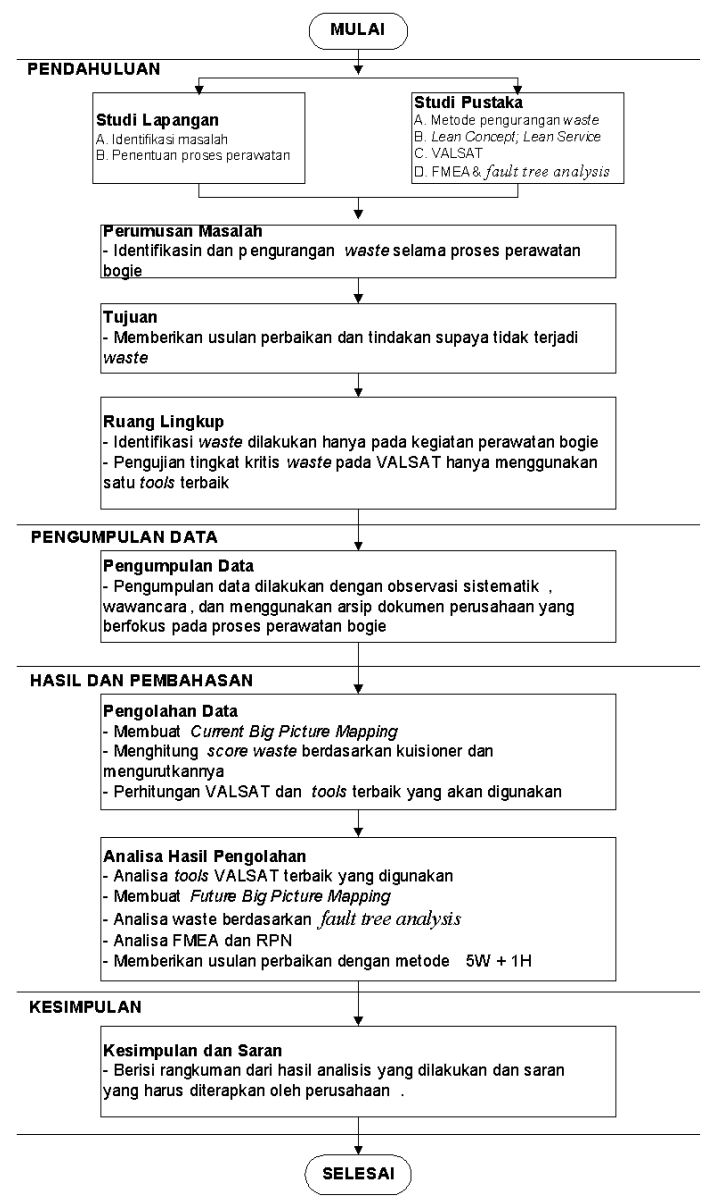

Gambar 3 Flowchart penelitian

\section{Metode Pengumpulan Data}

Dalam penelitian ini metode pengembilan data terdiri dari observasi, wawancara, pengarsipan dokumen serta pmberian kuesioner (detail dapat dilihat pada tabel 4).

Tabel 4 Metode Pengambilan Data

\begin{tabular}{|c|c|c|c|c|c|c|}
\hline \multirow{2}{*}{\multicolumn{2}{|c|}{ Data yang diperlukan }} & \multicolumn{4}{|c|}{ Metode Pengambilan Data } & \multirow{2}{*}{ Sumber Date } \\
\hline No. & & Observasi & Wawancara & Arsip & Kuesioner & \\
\hline 1 & Aliran proses produksi & & & 0 & & \\
\hline 2 & $\begin{array}{l}\text { Waktu siklus tiap } \\
\text { komponen }\end{array}$ & & & 0 & & \\
\hline 3 & Jadwal perawatan kereta & & & 0 & & \\
\hline 4 & Waste & 0 & 0 & & O & \\
\hline 5 & Defect & $\bullet$ & - & & & \\
\hline 6 & Jumlah pekerja & - & & - & & \\
\hline
\end{tabular}

\section{HASIL DAN PEMBAHASAN}

Current Big Picture Mapping (BPM)

Dari peta diatas didapatkan total waktu perawatansebesar 995 menit atau 16,6 jam. Dengan total waktu Value Added (VA) sebesar 931 menit, dan total waktu untuk Non-Value Adding (NNVA) adalah sebesar 64 menit.

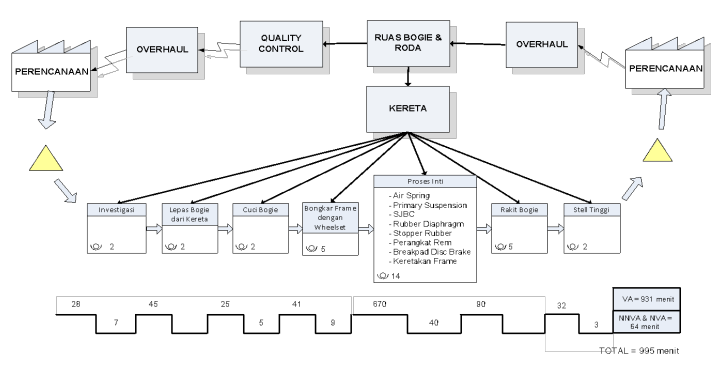

Gambar 4 Current big picture mapping

\section{Skor dan Urutan Waste Tertinggi}

Berdasarkan tabel 5 dapat dipahami bahwa skor rata - rata terbesar ada pada waste unnecessary inventory dengan skor sebesar 4,2. Dan skor rata - rata terkecil pada waste waiting yaitu sebesar 2,8 .

Tabel 5 Skor dan Ranking Waste

\begin{tabular}{|c|c|c|c|c|c|c|c|c|}
\hline \multirow[b]{2}{*}{ No } & \multirow{2}{*}{ WASTE } & \multicolumn{5}{|c|}{ RESPONDEN } & \multirow{2}{*}{$\begin{array}{l}\text { SKOR } \\
\text { RATA- } \\
\text { RATA }\end{array}$} & \multirow{2}{*}{ RANEING } \\
\hline & & 1 & 2 & 3 & 4 & 5 & & \\
\hline 1 & $\begin{array}{c}\text { Cinnocessay mation } \\
\text { (Geaklan jarg tidal. petu) }\end{array}$ & 2 & 3 & 4 & 4 & 4 & 3,4 & 1 \\
\hline 2 & 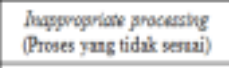 & 2 & 2 & 3 & 4 & 4 & 3 & 2 \\
\hline 3 & Waitivg (Menuggu) & 2 & 2 & 3 & 4 & 3 & 28 & 3 \\
\hline 4 & 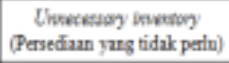 & 2 & 2 & 2 & 4 & 3 & 26 & 4 \\
\hline 5 & $\begin{array}{l}\text { Ohe prodisction (Produksi } \\
\text { betictih) }\end{array}$ & 0 & 0 & 0 & 0 & 0 & 0 & 5 \\
\hline 6 & Dofect (Produk cacst) & 0 & 0 & 0 & 0 & 0 & 0 & 6 \\
\hline 7 & $\begin{array}{l}\text { Ercesmive purpontution } \\
\text { (Transpertadi befletih) }\end{array}$ & 0 & 0 & 0 & 0 & 0 & 0 & 7 \\
\hline
\end{tabular}

\section{Value Stream Analysis Tools (VALSAT)}

Berdasarkan tabel 6, dapat dipahami bahwa total skor terbesar dimiliki oleh tools Process Activity Mapping (PAM) dengan total skor 98,4. Dari hasil perhitungan tersebut dapat ditentukan bahwa tools yang akan digunakan untuk mengidentifikasi value stream adalah Process Activity Mapping (PAM), karena memiliki skor terbesar dibandingkan dengan tools lainnya. 
Tabel 6 Perhitungan VALSAT

\begin{tabular}{|c|c|c|c|c|c|c|c|c|}
\hline WASTE & $\begin{array}{l}\text { RATA- } \\
\text { RATA } \\
\text { SKOR }\end{array}$ & $\begin{array}{l}\mathbf{P} \\
\mathbf{A} \\
\mathbf{M}\end{array}$ & $\begin{array}{l}\mathrm{S} \\
\mathbf{C} \\
\mathbf{R} \\
\mathbf{M}\end{array}$ & $\begin{array}{l}\mathbf{P} \\
\mathbf{V} \\
\mathrm{F}\end{array}$ & $\begin{array}{l}\mathbf{O} \\
\mathbf{F} \\
\mathbf{M}\end{array}$ & $\begin{array}{l}\mathbf{D} \\
\mathbf{A} \\
\mathbf{M}\end{array}$ & $\begin{array}{l}\text { D } \\
\text { P } \\
\text { A }\end{array}$ & $\begin{array}{l}\mathbf{P} \\
\mathrm{S}\end{array}$ \\
\hline Defects & 0 & - & - & - & - & - & - & - \\
\hline Over Production & 0 & - & - & - & - & - & - & - \\
\hline Waiting & 2,8 & 25,2 & 25,2 & 2,8 & - & 16,8 & 16,8 & - \\
\hline Transportation & 0 & - & - & - & - & - & - & - \\
\hline Un-Inventories & 2,6 & 15,6 & 23,4 & 15,6 & - & 23,4 & 15,6 & 2,6 \\
\hline Un-Motions & 3,4 & 30,6 & 3,4 & - & 30,6 & - & - & - \\
\hline In-Process & 3 & 27 & - & 18 & 3 & - & 3 & - \\
\hline Total & & 98,4 & 52 & 36,4 & 33,6 & 40,2 & 35,4 & 2,6 \\
\hline
\end{tabular}

\section{Process Activity Mapping (PAM)}

Pembuatan PAM mempertimbangkan beberapa faktor diantaranya aktivitas waktu yang dibutuhkan, jarak perpindahan pada setiap aktivitas, dan jumlah operator. Aktivitas dikelompokkan menjadi 5 kategori, yaitu operation (operasi), transportation (transportasi), inspection (inspeksi), storage (penyimpanan), dan delay (menunggu). Berikut adalah tabel 7, pengelompokkan tiap aktivitas:

Tabel 7 Pengelompokkan aktivitas

\begin{tabular}{cccc}
\hline Aktivitas & Jumlah & $\begin{array}{c}\text { Waktu } \\
\text { (menit) }\end{array}$ & $\begin{array}{c}\text { Value } \\
\text { Stream }\end{array}$ \\
\hline Operation & 60 & 931 & VA \\
Transportation & 3 & 14 & NNVA \\
Inspection & 4 & 50 & NNVA \\
Storage & 0 & 0 & - \\
Delay & 0 & 0 & - \\
\hline Total & 67 & 995 & \\
\hline
\end{tabular}

Setelah aktivitas yang terjadi dikelompokkan pada jenis value stream yang sesuai, selanjutnya dilakukan perhitungan presentase untuk melihat jenis aktivitas mana yang paling dominan. Berikut pada tabel 8 adalah hasil perhitungan persentase pada value stream:

Tabel 8 Total Presentase VA, NNVA, dan

\begin{tabular}{cccc}
\multicolumn{4}{c}{ NVA } \\
\hline $\begin{array}{c}\text { Value } \\
\text { Stream }\end{array}$ & $\begin{array}{c}\text { Banyak } \\
\text { Aktivitas }\end{array}$ & $\begin{array}{c}\text { Waktu } \\
\text { (menit) }\end{array}$ & Presentase \\
\hline VA & 60 & 931 & $94 \%$ \\
NNVA & 7 & 64 & $6 \%$ \\
NVA & - & - & - \\
\hline Total & 67 & 995 & $100 \%$ \\
\hline
\end{tabular}

Berdasarkan tabel 8 waktu yang dibutuhkan untuk seluruh proses perawatan bogie adalah selama 995 menit dengan total aktivitas sebanyak 67 aktivitas. Dari 67 aktivitas tersebut terdiri dari 60 aktivitas bersifat value added dan 7 aktivitas bersifat necessary non value adding dimana 7 aktivitas tersebut terdiri dari 4 aktivitas transportation dan 3 aktivitas inspection.

\section{Analisa VALSAT dengan Tool PAM}

Setelah dilakukan perkalian antara nilai korelasi dengan skor rata - rata dari waste didapatkan tools terbaik yang digunakan untuk mengidentifikasi value stream,yaitu process activity mapping (PAM). PAM digunakan untuk mengetahui lead time secara detil sehingga dapat mengidentifikasi setiap jenis aktivitas dan perbaikan yang diperlukan. Berikut adalah tabel usulan perbaikan terhadap beberapa aktivitas yang digambarkan pada tabel 9 PAM:

Tabel 9 Usulan Perbaikan pada PAM

\begin{tabular}{|c|c|c|c|c|c|c|}
\hline \multirow[t]{2}{*}{ No } & \multirow[t]{2}{*}{ Proses } & \multirow[t]{2}{*}{ Aktivitas } & \multirow{2}{*}{\begin{tabular}{|c} 
Jenis \\
Aktivi \\
as
\end{tabular}} & \multicolumn{2}{|c|}{$\begin{array}{c}\text { Waktu } \\
\text { Aktivitas } \\
\text { (menit) }\end{array}$} & \multirow[t]{2}{*}{$\begin{array}{l}\text { Value } \\
\text { Stream }\end{array}$} \\
\hline & & & & Awal & Jsular & \\
\hline 1 & $\begin{array}{l}\text { Investig } \\
\text { asi } \\
\text { Bogie }\end{array}$ & $\begin{array}{l}\text { Ukur } \\
\text { diameter } \\
\text { roda dan } \\
\text { tebal } \\
\text { flange }\end{array}$ & 0 & 22 & 12 & VA \\
\hline \multirow{5}{*}{2} & \multirow{5}{*}{$\begin{array}{l}\text { Cuci } \\
\text { Bogie }\end{array}$} & $\begin{array}{l}\text { Pindahka } \\
\mathrm{n} \text { bogie } \\
\text { ke } \\
\text { tempat } \\
\text { pencucia } \\
\mathrm{n} \text { bogie } \\
\text { dengan } \\
\text { crane }\end{array}$ & $\mathrm{T}$ & 5 & 5 & NNVA \\
\hline & & $\begin{array}{l}\text { Tutup } \\
\text { seluruh } \\
\text { permukaa } \\
\text { n air } \\
\text { spring. }\end{array}$ & 0 & 2 & 1 & VA \\
\hline & & $\begin{array}{l}\text { Siram } \\
\text { bogie } \\
\text { dengan } \\
\text { air } \\
\text { bertekan } \\
\text { an } \\
\text { sampai } \\
\text { merata }\end{array}$ & 0 & 5 & 3 & VA \\
\hline & & $\begin{array}{l}\text { Beri soda } \\
\text { api yang } \\
\text { sebelumn } \\
\text { ya sudah } \\
\text { dilarutka } \\
\text { n dengan } \\
\text { air. }\end{array}$ & 0 & 10 & 5 & VA \\
\hline & & $\begin{array}{l}\text { Bilas } \\
\text { dengan } \\
\text { air } \\
\text { bertekan } \\
\text { an } \\
\text { sampai } \\
\text { bersih. }\end{array}$ & 0 & 8 & 4 & VA \\
\hline & $\begin{array}{c}\text { Operasi } \\
\text { Inti }\end{array}$ & $\begin{array}{l}\text { Revisi } \\
\text { Perangka } \\
\text { t Rem }\end{array}$ & 0 & $\begin{array}{c}20 \\
0\end{array}$ & $\begin{array}{c}10 \\
0\end{array}$ & VA \\
\hline
\end{tabular}


Pada tabel 10 , usulan perbaikan diatas dapat dilihat terdapat perbandingan waktu aktivitas pada awal dan setelah usulan diterapkan. Berikut adalah perbandingan dan presentasetotal waktu dari PAM awal dan PAM setelah usulan:

Tabel 10 Perbandingan PAM Awal dan Usulan

\begin{tabular}{|c|c|c|c|c|}
\hline \multirow{2}{*}{ Aktivitas } & \multicolumn{2}{|c|}{$\begin{array}{l}\text { Jumlah } \\
\text { Waktu } \\
\text { (menit) }\end{array}$} & \multicolumn{2}{|c|}{$\begin{array}{l}\text { Persentase } \\
\quad(\%)\end{array}$} \\
\hline & $\begin{array}{c}\text { PAM } \\
\text { awa } \\
1\end{array}$ & $\begin{array}{c}\text { PAM } \\
\text { usula } \\
n\end{array}$ & $\begin{array}{c}\text { PAM } \\
\text { awa } \\
\text { l }\end{array}$ & $\begin{array}{c}\text { PAM } \\
\text { usula } \\
n\end{array}$ \\
\hline Operation & 931 & 809 & $94 \%$ & $93 \%$ \\
\hline $\begin{array}{c}\text { Transportatio } \\
n\end{array}$ & 14 & 14 & $1 \%$ & $2 \%$ \\
\hline Inspection & 50 & 50 & $5 \%$ & $6 \%$ \\
\hline Storage & 0 & 0 & 0 & 0 \\
\hline Delay & 0 & 0 & 0 & 0 \\
\hline TOTAL & 995 & 873 & $\begin{array}{c}100 \\
\%\end{array}$ & $100 \%$ \\
\hline \multirow{2}{*}{ Value Stream } & \multicolumn{2}{|c|}{$\begin{array}{l}\text { Jumlah } \\
\text { Waktu } \\
\text { (menit) }\end{array}$} & \multicolumn{2}{|c|}{$\begin{array}{l}\text { Persentase } \\
(\%)\end{array}$} \\
\hline & $\begin{array}{c}\text { PAM } \\
\text { awa } \\
1\end{array}$ & $\begin{array}{c}\text { PAM } \\
\text { usula } \\
n\end{array}$ & $\begin{array}{c}\text { PAM } \\
\text { awa } \\
1\end{array}$ & $\begin{array}{c}\text { PAM } \\
\text { usula } \\
n\end{array}$ \\
\hline VA & 931 & 809 & $94 \%$ & $93 \%$ \\
\hline NNVA & 64 & 64 & $6 \%$ & $7 \%$ \\
\hline NVA & 0 & 0 & $0 \%$ & $0 \%$ \\
\hline Total & 995 & 873 & $\begin{array}{c}100 \\
\%\end{array}$ & $100 \%$ \\
\hline
\end{tabular}

Pada tabel 10 waktu value stream activity mengalami perubahan pada value added activity dari 931 menit menjadi 809 menit, dengan presentase dari $94 \%$ menjadi $93 \%$.

\section{Future Big Picture Mapping (BPM)}

Berdasarkan hasil pengolahan BPM diatas dapat dipahami total lead time yang dibutuhkan untuk menyelesaikan satu kali proses perawatan bogie pada satu keretaadalah sebesar 873 menit atau 14,5 jam. Waktu tersebut mengalami penurunan yang signifikan dimana pada pengerjaan awal sebelum saran diterapkan memiliki total waktu sebesar 995 menit atau 16,6 jam (lihat gambar 5).

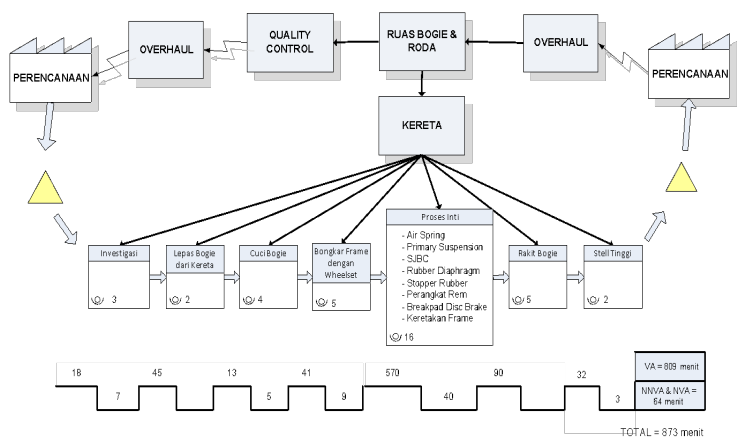

Gambar 5 Future big picture mapping

\section{Analisa Fault Tree Analysis}

Dari tabel 5 diketahui terdapat 4 waste yang terjadi pada proses perawatan bogie. Dari 4 waste tersebut selanjutnya dilakukan analisis dengan pohon akar masalah untuk diidentifikasi penyebab dari waste tersebut. Berikut pada gambar 6, adalah hasil analisis dengan pohon kesalahan:

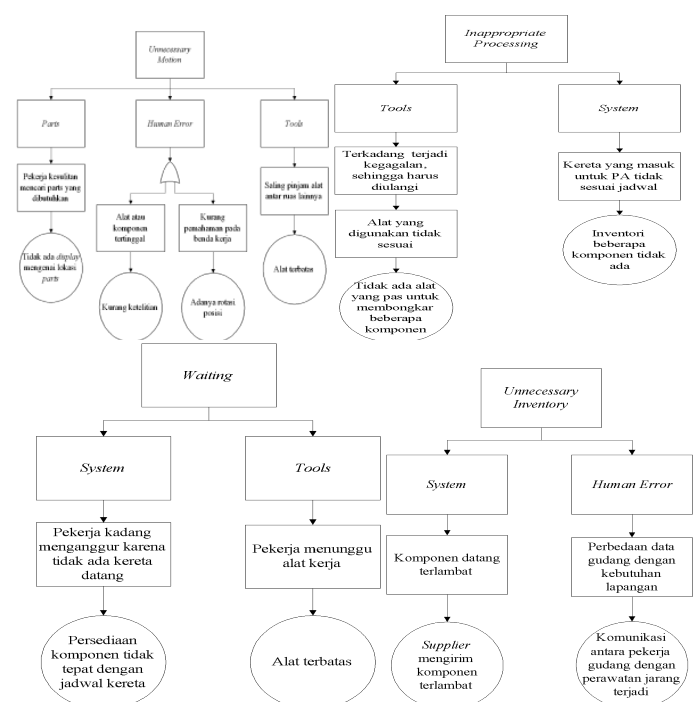

Gambar 6 Fault tree analysis dari masing masing jenis waste

\section{Analisa Failure Mode Effect and Analysis}

Dari hasil penjabaran faktor penyebab terjadinya waste pada diagram FTA diatas, selanjutnya dianalisis dengan menggunakan metode FMEA untuk mengetahui waste kritis yang diperlukan penanganan secepatnya. Maka langkah berikutnya adalah penentuan rating terjadinya waste berdasarkan dampak/pengaruh akibat waste (Severity), kemungkinan terjadinya waste (Occurance), dan deteksi waste (detection) seperti yang diperlihatkan pada tabel 11, 12 dan 13. 
Tabel 11 Skala Penilaian Severity

\begin{tabular}{|c|c|c|}
\hline Rating & Kriteria & Deskripsi \\
\hline 1 & $\begin{array}{l}\text { Tidak ada } \\
\text { akibat }\end{array}$ & $\begin{array}{c}\text { Pengaruh buruk yang dapat } \\
\text { diabaikan }\end{array}$ \\
\hline 2 & $\begin{array}{l}\text { Sangat } \\
\text { ringan }\end{array}$ & $\begin{array}{c}\text { Terjadi waste tetapi tidak } \\
\text { berpengaruh pada aktivitas } \\
\text { proses }\end{array}$ \\
\hline 3 & Ringan & $\begin{array}{c}\text { Terjadi waste dan } \\
\text { berpengaruh kecil pada } \\
\text { aktivitas proses }\end{array}$ \\
\hline $\begin{array}{c}4 \mathrm{~s} / \mathrm{d} \\
6\end{array}$ & Sedang & $\begin{array}{l}\text { Pengaruh buruk waste yang } \\
\text { moderat (masih berada } \\
\text { dalam batas toleransi) }\end{array}$ \\
\hline 7 & Tinggi & $\begin{array}{c}\text { Pengaruh buruk waste yang } \\
\text { tinggi (berada di luar batas } \\
\text { toleransi) }\end{array}$ \\
\hline 8 & $\begin{array}{l}\text { Sangat } \\
\text { Tinggi }\end{array}$ & $\begin{array}{l}\text { Pengaruh buruk waste yang } \\
\text { tinggi dan berpengaruh } \\
\text { pada proses lainnya }\end{array}$ \\
\hline 9 & Berbahaya & $\begin{array}{c}\text { Akibat yang ditimbulkan } \\
\text { berbahaya (berkaitan } \\
\text { dengan efektifitas proses } \\
\text { perawatan) }\end{array}$ \\
\hline 10 & $\begin{array}{l}\text { Sangat } \\
\text { Berbahaya }\end{array}$ & $\begin{array}{c}\text { Akibat yang ditimbulkan } \\
\text { berbahaya (berkaitan } \\
\text { dengan berhentinya proses } \\
\text { perawatan) }\end{array}$ \\
\hline
\end{tabular}

Tabel 12 Skala Penilaian Occurence

\begin{tabular}{ccc}
\hline Rating & $\begin{array}{c}\text { Tingkat } \\
\text { Kegagalan }\end{array}$ & Deskripsi \\
\hline 1 & Tidak ada & Tidak terjadi sama \\
sekali \\
2 & Sangat rendah & Terjadi $\leq 1 \mathrm{kali}$ \\
3 & Ringan & Terjadi $\leq 3 \mathrm{kali}$ \\
4 & & Terjadi $\leq 5 \mathrm{kali}$ \\
5 & Sedang & Terjadi $\leq 7 \mathrm{kali}$ \\
6 & & Terjadi $\leq 9 \mathrm{kali}$ \\
7 & & Terjadi $\leq 15 \mathrm{kali}$ \\
8 & Tinggi & Terjadi $\leq 20 \mathrm{kali}$ \\
9 & & Sering terjadi \\
10 & Sangat Tinggi & Selalu terjadi \\
\hline
\end{tabular}

Tabel 13 Skala Penilaian Detection

\begin{tabular}{|c|c|c|}
\hline Rating & Degree & Deskripsi \\
\hline 1 & $\begin{array}{l}\text { Hampir } \\
\text { pasti }\end{array}$ & $\begin{array}{c}\text { Sangat jelas, sangat } \\
\text { mudah diketahui }\end{array}$ \\
\hline 2 & $\begin{array}{l}\text { Sangat } \\
\text { tinggi }\end{array}$ & $\begin{array}{c}\text { Mudah diketahui namun } \\
\text { membutuhkan analisa }\end{array}$ \\
\hline 3 & Tinggi & $\begin{array}{l}\text { Membutuhkan analisis } \\
\text { pada } 1 \text { data lain }\end{array}$ \\
\hline 4 & & $\begin{array}{l}\text { Membutuhkan analisis } \\
\text { pada } 2 \text { data lain }\end{array}$ \\
\hline 5 & Sedang & $\begin{array}{l}\text { Membutuhkan analisis } \\
\text { pada } 3 \text { data lain }\end{array}$ \\
\hline 6 & & $\begin{array}{l}\text { Membutuhkan analisis } \\
\text { pada } 4 \text { data lain }\end{array}$ \\
\hline
\end{tabular}

\begin{tabular}{|c|c|c|}
\hline Rating & Degree & Deskripsi \\
\hline 7 \&8 & Rendah & $\begin{array}{c}\text { Memerlukan } \\
\text { departemen lain untuk } \\
\text { menganalisis }\end{array}$ \\
\hline 9 & $\begin{array}{l}\text { Sangat } \\
\text { rendah }\end{array}$ & $\begin{array}{l}\text { Kemungkinan besar } \\
\text { tidak dapat dideteksi }\end{array}$ \\
\hline 10 & $\begin{array}{l}\text { Hampir } \\
\text { tidak } \\
\text { mungkin }\end{array}$ & $\begin{array}{c}\text { Tidak ada alat kontrol } \\
\text { yang bisa digunakan } \\
\text { untuk mendeteksi } \\
\text { kesalahan }\end{array}$ \\
\hline
\end{tabular}

Selanjutnya langkah yang dilakukan yaitu menghitung masing masing bobot dari mode kegagalan sesuai dengan rating yang ditampilkan pada tabel 14 berikut ini:

Tabel 14 Usulan Perbaikan Dengan FMEA

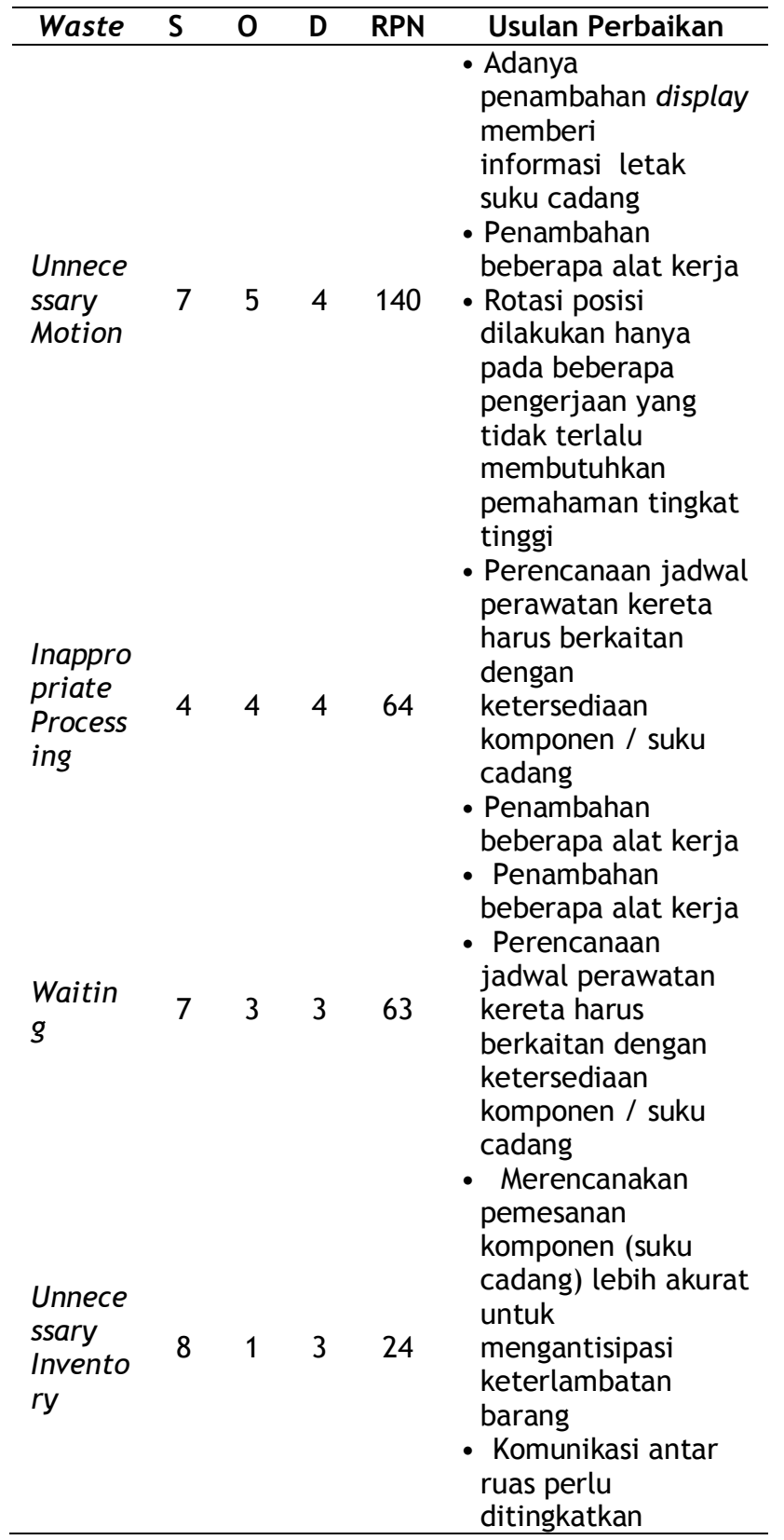


Berdasarkan tabel 14 , waste kritis yaitu unnecessary motion dengan nilai RPN sebesar 140. Prioritas kedua yaitu inappropriate processing, selanjutnya waiting, dan terakhir unnecessary inventory. Berdasarkan waste kritis tersebut maka dilakukan identifikasi usulan perbaikan menggunakan $5 \mathrm{~W}+1 \mathrm{H}$ sebagai berikut :

a. Apa saja kegagalan yang terjadi (What) ?

Waste yang terjadi yaitu pekerja memerlukan waktu lebih lama untuk mencari suku cadang yang dibutuhkan, pada proses perawatan terkadang pekerja bolak - balik ruang kerja dengan ruang bogie karena beberapa alat tertinggal, dan pekerja harus berjalan ke ruas lain untuk mengambil alat yang dipinjam atau untuk meminjam.

b. Kapan biasanya waste tersebut terjadi (When)?

Terjadi pada hampir seluruh proses perawatan bogie, misalnya adalah pembongkaran frame dengan bogie.

c. Siapa pekerja yang kemungkinan terlibat (Who) ?

Pekerja dari ruas bogie, pneumatic, dan body.

d. Dimana waste tersebut terjadi (Where) ? Di Departemen Overhaul

e. Kenapa waste tersebut terus berulang (Why) ?

Waste unnecessary motion disebabkan oleh 3 faktor, yaitu parts, human error, dan tools. Tiga faktor tersebut secara rinci dapat dijabarkan bahwa tidak adanya display mengenai lokasi suku cadang secara rapih, ketelitian pekerja pada saat bekerja terkadang teralihkan karena kelelahan dan mengobrol, terkadang terdapat pekerja yang belum ahli untuk menyelesaikan pekerjaan, dan terakhir karena minimnya alat kerja.

f. Bagaimana cara meminimisasi waste tersebut (How)?

1) Pertama, dari pihak manajemen Overhaul harus memberikan display yang memberikan informasi letak tiap suku cadang. Dengan adanya display, pekerja tidak akan kesulitan untuk mengambil suku cadang yang telah disediakan.

2) Rotasi posisi dilakukan hanya pada beberapa pengerjaan yang tidak terlalu membutuhkan pemahaman tingkat tinggi, sehingga pekerja yang baru pertama kali mengerjakan ruas bogie tidak akan kesulitan untuk menyelesaikan pekerjaannya, dan juga tidak akan mengganggu pekerja lain untuk membantunya.

3) Penambahan pekerja pada beberapa aktivitas perawatan dibutuhkan karena beban kerja yang cukup besar sehingga menyebabkan pekerja mudah lelah dan lepas dari konsentrasi.

4) Penambahan beberapa alat kerja sehingga pekerja antar ruas tidak perlu membuang waktu untuk berjalan ke ruang kerja ruas lainnya.

\section{SIMPULAN}

Dari hasil identifikasi tingkat waste dengan kuesioner, waste kritis yang sering terjadi adalah waste unnecessary motion (gerakan yang tidak perlu)dengan skor ratarata 3,4. Selanjutnya yaitu waste inappropriate processing (proses yang tidak sesuai) dengan skor rata-rata 3. Kemudian yang ketiga waste waiting (menunggu) dengan skor rata-rata 2,8. Waste urutan keempat yaitu unnecessary inventory (persediaan yang tidak perlu) dengan skor rata-rata 2,6. Kemudian dilakukan analisis FMEA didapatkan waste kritis yang dominan untuk dilakukan penanganan yaitu waste unnecessary motion dengan nilai RPN sebesar 140.

Usulan perbaikan untuk meminimisasi waste yang dominan dilakukan melalui dua pendekatan, yaitu dengan tool process activity mapping (PAM) dan dengan menggunakan analisis $5 \mathrm{~W}+1 \mathrm{H}$.

Process Activity Mapping (PAM)

a) Penambahan satu pekerja pada proses investigasi bogie dengan waktu siklus menjadi 12 menit.

b) Penambahan dua pekerja dan penambahan alat mencuci bogie waktu siklus menjadi 18 menit.

c) Penambahan pekerja sebanyak dua orang pada proses revisi perangkat rem, waktu siklus menjadi 100 menit per kereta.

Dari usulan perbaikan tersebut maka didapatkan total waktu pengerjaan (value stream) dari seluruh proses perawatan bogie adalah sebesar 809 menit dari yang sebelumnya 931 menit. Dengan pembagian presentase value added activity (VA) sebesar 93\% dan non - necessary value added activity (NNVA) sebesar $7 \%$. 


\section{DAFTAR PUSTAKA}

Adrianto, W \& Kholil, M. 2015. Analisis Penerapan Lean Production Process untuk Mengurangi Lead Time Process Perawatan Engine (Studi kasus PT. GMF AEROASIA). Jurusan Teknik Industri. Universitas Mercubuana. Jakarta. Jurnal Optimasi Sistem Industri Vol.14 No.2, 299 - 309.

Ferdiana, T. Dan Priadythama, I. 2015. Analisis Defect Menggunakan Metode Fault Tree Analysis (FTA) Berdasarkan Data Ground Finding Sheet (GFS) PT. GMF AEROASIA. Jurusan Teknik Industri. Universitas Sebelas Maret. Surakarta.

Hendri, John. 2009. Merancang Kuesioner. Riset Pemasaran. Universitas Gunadarma

Marastya, Avinda S. 2018. Analisis Pemborosan Dengan Lean Manufacturing Proses Produksi Kacang Shanghai Di Pt. $A b c$, Tulungagung, Jawa Timur. Jurusan Teknik Industri. Universitas Pembangunan Nasional "Veteran" Jakarta. Jakarta.

Setyaningsih, Ira. 2013. Analisa Kualitas Pelayanan Rumah Sakit Terhadap Pasien Menggunakan Pendekatan Lean SERVPERV (Lean Service dan Service Performance). Prodi Teknik Industri. UIN Sunan Kalijaga. Spektrum Industri Vol. 11, No. 2, 117 - 242. 
